\title{
Similarities and disparities between Romanian individual and consolidated financial group statements
}

\author{
Florentin - Emil Tanasă \\ Phd student, Doctoral School of Economics, "Alexandru Ioan Cuza” University of Iași \\ E-mail: tanasa.floretinemil@yahoo.com \\ Doina Prodan (căs. Palade) \\ Phd student, Doctoral School of Economics, "Alexandru Ioan Cuza” University of Iași \\ E-mail: doina_palade@yahoo.com
}

\begin{abstract}
:
The purpose of this study is to identify, analyse and assess the main connections and implications of consolidated accounts on enterprise economy. Appearance of consolidated financial statements is intrinsically linked to certain concepts, such as group, control, the perimeter of consolidation, percentages of interests, methods of consolidation, or restatements. For a more complete view regarding consolidated annual accounts, it is necessary to delimit and define these particular elements. This approach targets the presentation of our vision over positioning, place and function of financial consolidated statements in the process of the financial report.

The study envisages a summary and comparison of ideas found on this subject in thespecialty literature, the regulations developed by various international bodies. Thus, we think it will facilitate the correct positioning of the consolidated financial statements and the consolidated accounts' concepts. To achieve the proposed desiderates, we have used a constructive methodology for identifying disagreements, approvals and development of a speech to more efficient and effective management of the mentioned concepts.
\end{abstract}

\section{Keywords}

Consolidated financial statements, accounting standards, consolidation perimeter, percentages of interest.

Jel Classification: M40, M41.

\section{Introduction}

Worldwide, group as a form of organization is a topical issue considered by many accounting referential. In recent decades, this event has had a fulminant evolution, with implications in several areas of the economy and covers a wide range of sectors.

Recently, in the last 10-15 years, group companies have been created in Romania, but we expect the intensification of this phenomenon, on the basis of globalization and taking into account the current European and international context.

In some countries ${ }^{1}$, such as Germany, France, Italy and Japan, somegroup companies have to prepare two distinct sets of financial statements: both individual and consolidated, first based on existing national regulations and the consolidated based on international financial reporting standards.

\footnotetext{
${ }^{1}$ I., Goncharov, J., Werner, J., Yimmermann, (2009) Legislative Demands and Economic Realities: Company and Group Accounts Compared, pg. 3 , http://papers.ssrn.com/sol3/papers.cfm?abstract id $=880128$
} 
The two categories of financial statements are prepared for different reasons - the consolidated statements are made in order to provide a true and fair view of the financial position and performance of an economic entity and individual accounts are prepared for state institutions, mainly for information and taxation.From this point of view, each state legislator requires the companies to prepare individual reporting based on national standards.

\section{Preparation and presentation of individual and consolidated financial statements}

Individual accounts of groupc ompanies are independent and individual components of the consolidated accounts and support a series of transformations in order to bring to a common denominator elimination of disparities and transactions that occurred between group components. The consolidated accounts are prepared based on these financial statements.Finally, the consolidated financial statements aim to present an overview at group level as fair, transparent and close to economic reality, as possible.Both in terms of structure and in terms of content can be observed similarities and differences between the two sets of annual accounts.

The annual accounts main objective ${ }^{2}$ of is to provide a true and fair view of the financial position, assets and results of a particular entity to interested users.

Annual financial statements for entities applying accounting regulations harmonized with EU directives and international standards, approved by order of the Ministry of Finance, are composed of the following synthetic documents ${ }^{3}$ :

- for companies that exceed 2 of the size criteria at the balance sheet's date and for listed companies - financial statements with 5 components: balance sheet, income statement, statement of changes in equity, cash flow statement, notes to the financial statements (according to 3055/2009);

- if 2 of the size criteria are not exceeded - financial statements with 3 components: abridged balance sheets, profit and loss account and notes to the abridged annual financial statements simplified (as 3055/2009);

- peoplewho recorded low assets and turnover values in the previous financial yearabridged financial statements with 2 components: abridged balance sheets and abridged profit and loss account (under OMPF 2239/2011).

Annual and simplified financial statements are deposed to territorial units of the Ministry of Finance, along with two other forms: Other data and Non-current assets. When groups of companies, listed companies and other entities are subject to consolidation, they may prepare financial statements based on accounting regulations with European Directives or International Standards IAS / IFRS.

The International Accounting Standard IAS 1 Presentation of Financial Statements applies to all entities that report to the International Standards for the preparation of the annual accounts,being available for both individual preparation and presentation of financial statements and the consolidated accounts ${ }^{4}$.

The presentation of financial statements can be done either separately or within the same document, called the annual report, which is usually audited and the Board or other Governing Body has the responsibility to prepare and present of the annual accounts.

\footnotetext{
${ }^{2} \mathrm{C}$., Istrate, Introducere in contabilitate, Editura Polirom, Iași, 2002, pg. 163

${ }^{3}$ Ordinul 3055 din 29.10.2009 pentru aprobarea Reglementărilor contabile conforme cu directivele europene, Publicat în Monitorul Oficial al României, Partea I, Nr. 766 din 10.11.2009, Actualizat la 01.01.2011, http://www.dgnconsulting.ro/ordinul-3055-2009.html

${ }^{4}$ M. Gârbină, Ș., Bunea, Sinteze, studii de caz și testegrilă privind aplicarea IAS (revizuite)-IFRS, Vol. III, Editura CECCAR, București, 2008, pg. 173
} 
According to IAS 1, the annual accounts consist of following synthetic documents ${ }^{5}$ : balance sheet, comprehensive income statement, or profit and loss account, changes in equity or changes in equity other than those relating to contributions and shareholders equity withdrawals, flow statement treasury, annexes (i.e. accounting methods and explanatory notes).

Other items included in the annual report entities can be synthesized by a management report containing an analysis of the factors influencing the performance of the company, sources of financing, investment policy, risk management policy, company resources and benefits that are not presented in the balance sheet.

\subsection{Balance sheet}

Internationally, the accepted formats for presenting the results are ${ }^{6}$ : account (tracks the relationship Assets $=$ Equity + Payables or Assets $=$ Liabilities) and list (on the basis of equality assets - liabilities $=$ total equity).

The balance sheet consolidated by the global integration financial method reflects the broadest economic and financial view over the control the dominant society exertsover the subsidiaries.

When applying the method of global integration, consolidated balance sheet will contain new items, in liabilities ${ }^{7}$ :

-consolidated reserves - that include reserves of the dominant company and those of the controlled entity, belonging to the group, beginning with the date of the its consolidation;

-consolidated result - includes both outcome of the dominant entity and the corresponding share of the controlled company results;

-minority interests - refers to the share of the subsidiary's equity held by shareholders outside the consolidation perimeter of the group.

-consolidated debts - consisting of debts and liabilities of the entity that controls the controlled company.

Specific elements of the consolidated balance sheet as OMPF 3055/2009 are:

-presentation of amounts attributable to shares in subsidiary undertakings included in the consolidation, held by persons other than companies included in the consolidation, separately, under "non-controlling (minority) interests".

-minority interests must be presented separately from the equity of the parent-company.

\subsection{Profit and loss statement}

The emergence of income statement is confirmed in the second half of the fourteenth century, being, to some degree dependent on the balance sheet developments.Income statement is, to some extent, as an extension of the balance that brings clarification of changes in equity other than those resulting from contributions or redistributed.

Regarding the consolidated profit and loss statement, after consolidation by global integration method will include a new item "minority interests", which reflects the share of the result of the controlled company, which returns to shareholders outside the group.This post does not appear in the case of proportional integration method.

\footnotetext{
${ }^{5} \mathrm{M}$., Ionașcu, I., Ionașcu, Raportarea financiară conform normelor contabile internaționale (IASIFRS),Editura Tribuna Economică, București, 2007, pg. 16

${ }^{6}$ N., Tabără, E., Horomnea, C., Toma, Conturile anuale in procesul decizional - Elemente de contabilitate, analiză financiară și evaluarea performanțelor întreprinderii, Editura Tipo Moldova, Iași, 2001

${ }^{7}$ A., Tiron, Tudor, Consolidarea conturilor, Editura Tribuna Economică, București, 2000, pg. 59
} 
According to IAS 1 Presentation of Financial Statements, posts which must appear in the consolidated income statement can be summarized as follows: the current activity income, finance costs, share of results of associates, or companies put into equivalence gross result after out of assets or liabilities of discontinued operations, income tax expense, net profit or loss of the year, net income distribution between groups and minorities.

IAS 1 standard allows classification of expenses in case the results are by nature (raw materials costs, depreciation costs, salary costs) or by destination / their function - selling cost method (cost of sales, administrative expenses, selling expenses).

The first way of classifying costs is easier for small and medium companies, but the second provides information most relevant to users of financial accounting information.

However, regardless the method of presentation of expenses in the income statement chosen by a company, IAS 1 standard states that it is also necessary the presentation of expenses on the basis of the other method, in annexes.

According to national regulations (OMFP 3055/2009), in the consolidated profit and loss account there is presented separately the value of any profit or loss attributable to shares in subsidiary undertaken included in the consolidation held by persons other than the entities included in consolidation, at the post "profit or loss of the financial year of the noncontrolling interests $" 8$.

\subsection{Cash flows}

Cash flows ${ }^{9}$ reflect all incoming and outgoing cash and cash equivalents.Available funds comprise cash and demand deposits, and short-term investments aimed equivalents, easily convertible.

As concern the evolution of the financial situation,there is alack of a management company in the difference between an increase in turnover and production and a reduction in treasury. In this respect, it should also be considered aspects of investment activity conducted by the company, or the means used by the entity.

The panel of the cash flowsdesignates the liquidity and flexibility of an enterprise. Liquidity refers to the time required to convert an asset to cash, or for payment of current liabilities, an increased liquidity indicating a lower risk of bankruptcy.

Regarding the Company's ability to pay its due debts nor balance sheet nor profit and loss account does not provide enough information, for whichthe cash flow statement is an important tool for assessing the liquidity and solvency of the company.

Funding panel includes cash outflows (payments) and inflows (receipts) incurred duringan accounting period, thus giving origin cash, but its causes and how to change them.

International Standard IAS 7 Statement of Cash Flows applies to all companies required to prepare financial statements with five elements, regardless of the type of activity carried out. Depending on the type of activity that generates cash flows are classified into operating activities, investing activities or financing activities. The size of the three categories of cash flows are indicators of availability in relation to variations in operating activities, investing or financing.

According to IAS 7 Statement of Cash Flows, cash flows from operating activities are determined using either:

- The direct method, whereby major classes of gross cash receipts and gross cash payments are disclosed; or

\footnotetext{
8***, Ordinul 3055 din 29.10.2009 pentru aprobarea Reglementărilor contabile conforme cu directivele europene, Publicat în Monitorul Oficial al României, Partea I, Nr. 766 din 10.11.2009, Actualizat la 01.01.2011, http://www.dgnconsulting.ro/ordinul-3055-2009.html, accesat la data de 20.05.2012, ora 22.49

${ }^{9}$ A., Tiron, Tudor, Consolidarea conturilor, EdituraTribuna Economică, București, 2000, pg. 183
} 
- The indirect method, whereby profit or loss is adjusted for the effects of transactions of a non-cash nature, any deferrals or accruals of past or future operating cash receipts or payments, and items of income or expense associated with investing or financing cash flows.

Under the indirect method, the net cash flow from operating activities is determined by adjusting profit or loss for the effects of:

- Changesduring the period in inventories and operating receivables and payables;

- Non-cash items (provisions, depreciation, deferred taxes, non-controlling interests);

- Adjustments for cash outflows or inflows, relating to future or past financial exercises.

IAS 7 encourages reporting cash flows from operating activities using the direct method, which provide more information to users.

\subsection{Change in equity}

The most relevant form of reflectingthe financial development entity is statement of changes in shareholders' equity, in fact, reflecting changes in net asset value over a period.

Statement of changes in equity may be prepared in two ways: either exhaustive presentation of information on changes in equity elements in this case, or disclosure of some further information, in the explanatory notes to the financial statements.

The main elements contained in this synthetic document under Accounting Standard IAS 1 Presentation of Financial Statements, are the following:

- Net profit or loss for the period;

- Items of income and expense recognized directly in equity (as a result of compliance with the International Standards or Interpretations) and the total of these items;

- Total comprehensive income for the period, showing separately amounts attributable to owners of the parent and to non-controlling interests;

- Effects of changes in accounting policies and correction of errors in accordance with IAS 8 Accounting Policies, Changes in Accounting Estimates and Errors.

Among the events that generate income and expenses recorded in equity category, we can mention: changing accounting methods, revaluations, correction of errors, the occurrence of conversion differences consolidation, recognizing changes in the fair value of certain financial instruments ${ }^{10}$.

The entity's total change in equity as determined after excluding changes resulting from transactions conducted in relation to shareholders/associates is a measure of profit or lossfor the company's activity during a reporting period.

\section{Particulars of consolidated financial statements in accordance with International Standards}

International Financial Reporting Standards comprise a number of issues specific to large companies that prepare consolidated financial statements. Of such information, we can mention: changes in currency exchange rates, tax, reporting in hyperinflationary economies, interim financial statements, segment reporting activity, changes in accounting policies and corrections of errors, earnings per share and events after the reporting period.

\footnotetext{
${ }^{10}$ C., Istrate, Contabilitatea nu-i doar pentru contabili, Editura Universul Juridic, București, 2009, pg. 300
} 


\subsection{Income Taxes}

According to accrual accounting principle,the result and the related income tax must be recorded in the appropriate accounting financial year transactions they generated, regardless of the time of actual payment (early or later).

Income tax is determined using the taxable profit of the entity and not the carrying amount ${ }^{11}$. If the accounting result is calculated by subtracting total expenses from total income amount, taxable result is based on the result sheet, plus taxable expenses, related to this period and deducted taxable income and tax loss carry forwarded by the company.

Therefore, tax law is the origin of differences between taxable and accounting profit.

As required by the International Standard IAS 12 Income Taxes, when the taxation of income and deductibility of expenses is made in another financial year, deferred tax is taken into account.

In countries where accounting is connected with taxation, such as Germany or Japan, deferred tax sources are not numerous and its values are not significant, even at the consolidated level.

On the contrary, Anglo-Saxon countries are characterized by a clear separation of the accounting and fiscal rules, having as a result, considerably higher amounts of deferred $\operatorname{taxes}^{12}$.

The differences arising between the taxesand accounting result fall into two categories ${ }^{13}$ :

- Permanent differences, comprising expenses accounted for, but not deductible and income counted but excluded from the tax base;

- Temporary differences arising from the accounting for revenues and expenses to be included or deducted from the following year's fiscal results and the integration or deduction of income or expenses that have not yet been accounted for.

The international standard IAS 12 establishes categories of temporary differences that may occur:

- taxable temporary differences, which involves increasing tax income in a future period, when crossing the costs of that asset or extinguishment of the debt that has caused these temporary differences;

- deductible temporary differences, which are reflected in reduced tax income in future periods will be recovered when the asset value or amount of the debt will be extinguished on which they occurred.

Taxable temporary differences - deferred tax liabilities, intervene in situations where: the tax value of an asset is less than its carrying amount, or if the tax liability is greater than its carrying amount.

Reverse situations will result in deductible temporary differences - Deferred tax claims or tax loss carried forward. There are no temporary differences relating to the initial recognition of assets or liabilities of, or goodwill.

A noteworthy aspect is that a deferred tax claim is not accounted for if it is not likely that the company will have sufficient taxable favourable results in the following financial.

If you make a credible justification that there will be future taxable profits sufficient to cover the loss carried forward, shall disclose the deferred tax claim in annexes annual accounts of the entity.

\footnotetext{
${ }^{11} \mathrm{~F}$., Scorțescu, Consolidarea conturilor grupurilor financiare, Editura Ion Ionescu de la Brad, Iași, 2008, pg. 143

${ }^{12}$ N., Tabără, E., Horomnea, C., Toma, Conturile anuale în procesul decizional - Elemente de contabilitate, analiză financiară și evaluarea performanțelor întreprinderii, Editura Tipo Moldova, Iași, 2001, pg. 238

${ }^{13}$ M. Gârbină, Ș., Bunea, Sinteze, studii de caz și testegrilă privind aplicarea IAS (revizuite)-IFRS, Vol.

II, Editura CECCAR, București, 2007, pg. 178
} 
Otherwise, no such claim is accepted registration, and every subsequent closure, have one further reassessments of deferred tax claim and can account for the asset entity that future taxable profits is probable.

\subsection{Subsequent events}

There are certain events occurring after the date for submission of annual accounts thathave significant effects on presence information for the period ended.IAS 10 Events after the Reporting Period provides information that must be presented in relation with events after the balance sheet date and the moment that requiresadjustment of the financial statements for adjusting events - events after the balance sheet date that provide further evidence of conditions that existed at the end of the reporting period ${ }^{14}$.

Subsequent events are considered those events that occur between the end of the reporting period and the date that the board of directors authorizes the issue of financial statements. Some provide evidence of conditions that existed at the balance sheet date (adjusting events after the balance sheet date) and others are indicative of conditions that arose after the balance sheet date (non-adjusting events after the balance sheet date) ${ }^{15}$.

IAS 10 states events thatinvolve adjustments of the annual accounts:

- settlement of litigation against the entity after the reporting date may provide evidence of the existence of liability at the reporting date;

- information after the balance sheet date, indicating impairment of asset items that confirm the existence of an obligation;

- detection the existence of errors or fraud - financial statements are incorrect;

- determinationthe cost of assets for which the acquisition cost cannot be calculated accurately by the balance sheet.

Non-adjusting events that occur after the end of reporting period are:

- natural disaster occurring after the end of reporting period, with significant impacts on the activity;

- changes in tax laws or tax rates enacted or announced after the reporting period that have a significant effect on current and deferred tax;

- initiation of litigation arising out of events that occurred after the reporting period;

- abnormally large changes after the reporting period in foreign exchange rates;

- disposal of securities held in the capital of an important subsidiary;

- majorshare transactions, association or involvement in a combination of companies.

IAS 10 provides that the entity shall notprepare financial statements on the going concern basis if events after the reporting period indicate that the entity shall not be able to continue as a going concern.

\section{Conclusions}

Groupstructureshave appeared as a result of the development strategies adopted by the companies.Among them, note the following two possibilities: either maintaining the legal unit of the entity and it creates new departments or branches, or creating new companies (or buying existing companies), with separate legal personality under the control of the dominant society.Foreign development underlies the emergence of groups of companies.

\footnotetext{
${ }_{14 * * *}^{14}$ IASIO - Events after the reporting period, http://www.iasplus.com/en/standards/standards/standard9,

${ }^{15}$ H., Greuning, D., Scott, S., Terblanche, Traducere: T., Cabsan, Standarde Internaționale de Raportare Financiară - Ghid practic,Ediția a VI-a, Editura Irecson, București, 2011, pg. 626
} 
In order to eliminate the difficulties of assessing the financial position and profitability third component companies of a group should be established to consolidated financial statements (accounts group).

Separate financial statementsdo not provideenough information to form a fair and global image of the group.In order to build consolidated information is made restatements and aggregations of data on parent society, and the entities under its control.

Consolidated financial statements reflect a situation actually complementary to individual accounts, ties given by capital between companies within the group, and presenting an overview of the group's financial structure and profitability.

Given the economic reality, with a strong competitive and that the main objective of the group companies is to create value for shareholders, we can say that the consolidated financial statements are a relevant tool information for interested users.

\section{Bibliography}

1. N., Feleagă, L., Feleagă, Contabilitate consolidată - O abordare europeană şi internațională, Editura Economică, București, 2007

2. M. Gârbină, Ș., Bunea, Sinteze, studii de caz și teste grilă privind aplicarea IAS (revizuite)-IFRS, Vol. I, Editura CECCAR, București, 2007

3. E., Horomnea, Dimensiuni științifice, sociale și spirituale în contabilitate, Ed. Tipo Moldova, Iași, 2012;

4. E., Horomnea, Tabara N., Budugan D., Georgescu I., Beţianu L., Dicu R. M. - Introducere în contabilitate. Concepte şi aplicaţii, Ed. Tipo Moldova, Iaşi, 2011;

5. C., Istrate, Contabilitatea nu-i doar pentru contabili, Editura Universul Juridic, București, 2009

6. C., Istrate, Issues related to the impact of the IAS/IFRS implementation in Europe, Quality Management of Accounting information, Editura Universitătii “Alexandru Ioan Cuza”, Iași, 2008

7. N., Tabără, E., Horomnea, C., Toma, Conturile anuale în procesul decizional - Elemente de contabilitate, analiză financiară și evaluarea performanțelor intreprinderii, Editura Tipo Moldova, Iași, 2001

8. F., Scorțescu, Consolidarea conturilor grupurilor financiare, Editura Ion Ionescu de la Brad, Iași, 2008

9. A., Seetharaman, M. Krishna Moorthy, A. S. Saravanan, A new approach to the preparation of consolidated financial statements of group companies, The Review of Financial and Accounting Studies, Euro Journals Publishing, 2011

10. ***Convergence with the International Accounting Standards Board, http://www.fasb.org/intl/convergence iasb.shtml,

11. ***GAAP vs. IFRS, http://www.termpaperwarehouse.com/essay-on/Gaap-Vs-Ifrs/58929.

12. ***Ordinul 3055 din 29.10.2009 pentru aprobarea Reglementărilor contabile conforme cu directivele europene, Publicat în Monitorul Oficial al României, Partea I, Nr. 766 din 10.11.2009, Actualizat la 01.01.2011, http://www.dgnconsulting.ro/ordinul-3055-2009.html, 